\begin{tabular}{|c|l|}
\hline \multicolumn{2}{|c|}{ 日本一中国 $\begin{array}{l}\text { 国際共同研究「環境・エネルギー分野」 } \\
2020 \text { 年度 年次報告書 }\end{array}$} \\
\hline 研究課題名 (和文) & $\begin{array}{l}\text { 下水再生利用におけるエネルギー回収と健康リスク管理 } \\
\text { の実現 }\end{array}$ \\
\hline 研究課題名 (英文) & $\begin{array}{l}\text { Energy recovery and pathogen risk management in } \\
\text { wastewater reclamation by anaerobic membrane } \\
\text { bioreactors }\end{array}$ \\
\hline 日本側研究代表者氏名 & 佐野 大輔 \\
\hline 所属・役職 & 東北大学大学院環境科学研究科・准教授 \\
\hline & 2019 年 4月 1日 2022 年 3月 31日 \\
\hline 研究期間 & 3月 \\
\hline
\end{tabular}

1. 日本側の研究実施体制

\begin{tabular}{|l|l|l|}
\hline \multicolumn{1}{|c|}{ 氏名 } & \multicolumn{1}{|c|}{ 所属機関・部局・役職 } & \multicolumn{1}{c|}{ 役割 } \\
\hline 佐野大輔 & $\begin{array}{l}\text { 東北大学・大学院環境科学研究 } \\
\text { 科・准教授 }\end{array}$ & $\begin{array}{l}\text { AnMBR によるウイルス除去効率評 } \\
\text { 価 }\end{array}$ \\
\hline 李玉友 & $\begin{array}{l}\text { 東北大学・大学院工学研究科・ } \\
\text { 教授 }\end{array}$ & AnMBR 運転条件最適化 \\
\hline
\end{tabular}

2. 日本側研究チームの研究目標及び計画概要

実下水を処理する嫌気性膜分離法のパイロットプラントの運転を継続的に行う。嫌気性 処理の安定稼働時の未処理下水水質 - 処理水水質 $(\mathrm{pH}$ 、水温、アルカリ度、窒素、BOD、 $\mathrm{COD}$ )、メタンガス発生量および運転条件（水理学的滞留時間、水温、膜間差圧）を得る。 同時に、未処理下水中のウイルス濃度を定量する。未処理下水中のウイルス濃度は季節に より変動することが予想されるので、 1 年を通じて定期的に定量を行い、未処理下水中ウ イルス濃度を確率分布として表現する。 


\section{3. 日本側研究チームの実施概要}

嫌気性 MBR による実下水に対する浄化性能を把握することを目的として、前年度宮城県内の 下水処理場に設置した嫌気性 MBR を継続して運転し、2 $5{ }^{\circ} \mathrm{C}$ の条件で水理学的滞留時間 (hydraulic retention time: HRT) を 24 時間から $12 ， 8 ， 6$ 時間と段階的に変え、BOD や COD、窒素、リンなどの処理水質、バイオガス発生量、余剩污泥発生量、膜運転の安定性などを調 査した。同時に、流入下水及び処理水中のウイルス濃度を定量し、ウイルス除去効率を評価した。具体的成 果は次の通りである。

\section{1 処理水質}

すべての条件において COD と BOD 除去率は 90\%と高い値を維持した。BOD 除去率が 95\%以上にな ることもあった。標準活性污泥法に比べると、同じ処理条件（HRT6h）では高い除去率が得られた。長期運 転において処理水の BOD が基準値 $10 \mathrm{mg} / \mathrm{L}$ 以下であった。一方、窒素とリンはそれぞれアンモ二アとリン酸の 形態で処理水に残存していた。

\section{2 バイオガス生成}

嫌気性 MBR 全期間のバイオガス発生率は 0.11 L/L（1 L の原水から 0.11 Lのバイオガスが 発生した）になり、メタン発生率は 0.08 L/L（1 L の原水から 0.08 Lのメタンガスが発生でき た）であった。バイオガス中のメタン濃度は 76〜80\%の範囲にあった。

\section{3 余剰污泥生成率}

嫌気性 MBR における COD の嫌気性污泥 MLSS 転化率が 0.188〜 $0.277 \mathrm{~g} / \mathrm{g}$ COD 除去であ り、MLVSS 転化率は 0.168 0.213g/g COD 除去であった。この結果は、通常の嫌気性処理の 污泥 COD 污泥転化率より少し高くなつたが、従来の好気性活性污泥法に比べると $1 / 3$ 程度と低 い値であった。

4 膜乃過性能

膜運転モードを 4 分吸引 1 分休止とし，次亜塩素酸ソーダとクエン酸による定期的インライン 洗浄を行うことで、膜フラックスを 0.055 0.27m/d で長期間運転することができた。特に大 型パイロットプラント嫌気性 MBR で $0.27 \mathrm{~m} / \mathrm{d}$ で運転できたことは応用の可能性を示唆してい る。

\section{5．ウイルス除去効率}

ヒト糞便や環境水中に豊富に存在する植物ウイルスであり，近年環境水中のヒト糞便污染指標 の候補ウイルスとして活用するための研究が進んでいる Pepper mild mottle virus (PMMoV) をテストウイルスとして用いた。嫌気性 MBR による PMMoV 除去率は 2.91 ( \pm 0.42$) \log$ であ つた。 